\title{
PROLEGOMENA: SOCIAL POTENTIAL OF THE ORGANIZATION VERSUS ENGAGEMENT AND JOB SATISFACTION*
}

\author{
Renata Winkler \\ Cracow University of Economics, Cracow, Poland \\ Institute of Quality and Product Management Sciences \\ e-mail: winklerr@uek.krakow.pl \\ ORCID: 0000-0002-4697-9264 \\ Marta Moczulska \\ University of Zielona Góra, Zielona Góra, Poland \\ e-mail:m.moczulska@wez.uz.zgora \\ ORCID: 0000-0002-1390-2914 \\ (C) 2019 Renata Winkler, Marta Moczulska \\ This is an open access article distributed under the Creative Commons Attribution-NonCommercial-NoDerivs license \\ (http://creativecommons.org/licenses/by-nc-nd/3.0/) \\ DOI: $10.15611 / \mathrm{ms} .2019 .3 .05$ \\ JEL Classification: D23, D91, M12, M54
}

\begin{abstract}
The article focuses on the Social Potential of the organization. In accordance with the adopted objective, the components of the potential were described and the conditions of its shaping in the organization were characterized. Taking into account the possible states of combinations of the discussed potential factors, the types of situations important for the assessment of possibilities activating potential were proposed. They were analysed, on the one hand, indicating activities in the field of organization policy, appropriate for shaping, using and developing the potential, and on the other - showing the complexity of the issue and difficulties in the selection of the type of activities. The article shows the role of engagement and satisfaction in this area. It analyses the potential in relation to an individual, a group and an organization.
\end{abstract}

Keywords: Social Potential, organization, job satisfaction, engagement.

\section{Introductory remarks}

In the publications in the field of organization and management, the importance of the human factor has an established position. Most authors agree that the efficiency of business entities (their innovation and efficiency in adapting to changes occurring in the environment) depends to a large extent on the qualifications, knowledge, skills, experience, predispositions, motivation and commitment of people employed in them [Janowska, Skrzek-Lubasińska 2019, pp. 62-63; Grabowska et al. 2018, pp. 138-139].

The attention is also drawn to the fact that the loss of key employees by organizations is associated with a number of severe and difficult to predict consequences.

At the same time, it is worth paying attention to confirmed cases when people without appropriate qualifications, skills or professional experience in a specific area (often without relevant knowledge crucial to the implementation of a specific type of tasks) in practice with these tasks were able to cope with the same level (and even more efficiently) as employees in relation to whom it is possible to document the required qualifications, skills, experience (and knowledge) (compare with: [Hysa, Grabowska 2017, p. 110]). This is significant because the pace and scope of the civilization and technological changes

* The publication was financed from the funds granted to the Faculty of Management of the Cracow University of Economics within the framework of the subsidy for the maintenance of research potential. 
currently underway often put organizations in a situation in which they are able to predict to a very limited extent what challenges they will have to cope with. Organizations are thus often forced to improvise - and, as a result, to rely on the employees' ability to behave in the right way under new circumstances [Becton, Schraeder 2009, pp. 11-12].

Such a hypothetical ability of the individual to adapt and develop is referred to as potential [Smykowski 2019, p. 127]. Potential is a category understood quite intuitively. As a hypothetical ability, it may or may not reveal itself. However, according to G. Lasiński [2016, p. 113], it can be used, developed or wasted.

An organization is made up of people - thus, each organization is a social structure, the structure within which individuals and groups function. The aim of this study is to indicate what constitutes the employee's potential and assessment of how (and perhaps to what extent) the organization may have an impact on shaping the employees' potential and to assess the role of engagement and satisfaction in this respect. Importantly, the article analyses the category which is the potential, not only in relation to the individual - but also in relation to the group of individuals - and therefore the group and the entire organization is treated as a social system.

\section{Potential of (in) the organization}

The analysis of the contemporary literature on the subject of management in relation to the human factor recognized as potential indicates that in principle this concept is used in three different conceptual combinations: employee potential, Social Potential in the enterprise/organization, Social Potential of the organization/enterprise.
S. Smoleński [2001, p. 75] defines Employee Potential as "employee engagement that can be achieved, translating into specific results, depending on the impact on $\langle<$ hard $>>$ and $<<$ soft $>>$ elements of their competences".

Social Potential in the Organization, Z. Pawlak and A. Smolen [2007, p. 278] refer to people doing work for the company with their knowledge, experience, skills, abilities, predispositions to work, motivation and health. At the same time, they emphasize that the word "potential" means that certain human abilities and talents may be revealed and realized only after certain conditions are met.

According to E.I. Полякова [2008, pp. 15-20], Social Potential of the Organization is the level of civic awareness and social maturity, the degree of assimilation (adoption) by the employee of labour standards, value orientation, interests, needs and requirements in the field of work, based on the hierarchy of human needs. In turn, Н. Скляр, I. О. Зверкович (as cited in: [Коваль 2012, p. 175]) recognize that "the Social Potential of an industrial enterprise consists of two interrelated elements: administrative (conditions for creation and development of Social Potential) and personal (intellectual, adaptive, physical and other potential)". However, according to B. Mikuła [2014 p. 82], Social Potential should be understood as "a complex of possibilities and abilities of an organization in changing and different conditions resulting from the collective use of the ability to use resource systems in the possession and disposal of people working for this organization".

It can be noticed that the described ways of recognizing the potential show three possible levels of its consideration in the organization - individual, group and organizational (Fig. 1).

In the first case, a complex of capabilities and abilities of each person employed in the organization

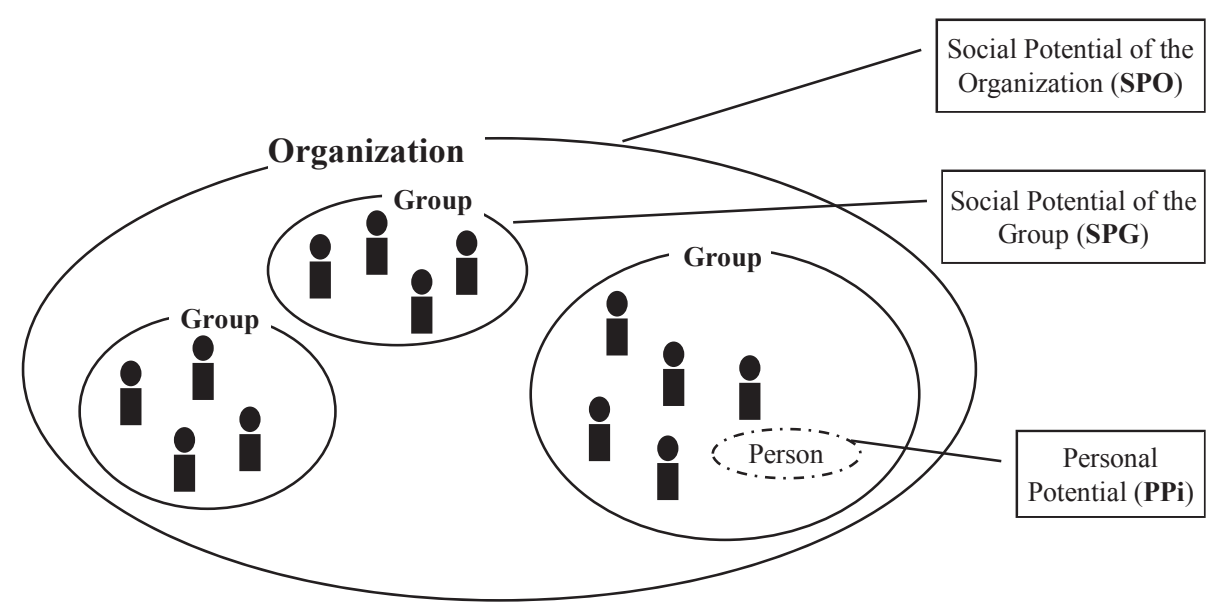

Figure 1. Scopes of considering Social Potential in organization management

Source: own study. 
(discussing this level we can say about personal potential - PPi) may be analyzed and evaluated. Due to the fact that teams and group cooperation are considered as an important element of the strategy of running a business in highly competitive conditions, it seems justified to assess the Social Potential of the Group (SPG), it means jointly owned potential of people who are formally included in the work with specific task. The last level (Social Potential of the Organization SPO) applies to all employees, to the entire community of people making up the organisation.

At the same time, it seems reasonable to say that these levels remain interrelated - each previous one is part of the next ${ }^{1}$. Therefore, the effective management of potential requires not only taking care of each level separately, but also all together.

Taking into account the content of presented definitions, it can also be stated that the Social Potential (compare with: [Jamka 2011, p. 225]) will concern, on the one hand, the individual scope of the individual's capabilities, on the other - their "use", i.e. the causative role of the enterprise in the activation of these opportunities.

It is worth distinguishing here the notion of "potential" from the term "resource" used in definitions and having an established position in the subject literature; or also the word "capital", which not only refers to the human factor, but which also means the increasing frequency of use (Fig. 2). In the case of treating people as "resource" ("resource orientation"), the focus is on the "quality" of the resource, which is people, and thus the focus on improving this quality. In the case of the term "capital" ("capital orientation"), it becomes important to obtain a return on investment, in other words: using the contracted possibilities.

In the opinion of B. Jamka [2011, pp. 229, 298-299, 304-305, 323], it is possible to point to the arrangement of these concepts: the resource $\rightarrow$ capital $\rightarrow$ potential, which in a way corresponds to a specific "logical sequence" of perceiving people in an enterprise. The sequence reflects the degree of acceptance of the fact that the efficiency of the human factor in the organization is neither in a straight line, nor a derivative of their "objective quality", nor "return on investment" resulting from the use of the contracted possibilities. At the time of employment, the whole person is acquired, not only his/her qualifications, skills and experience. Interestingly, according to M. Belbin, with limited competences, having the potential is much more important than having adequate qualifications with limited potential (lack of development opportunities) (compare with: [Costello 2011, p. 26]). It is worth emphasizing that the potential of a particular individual is determined by something more than just the individual's predispositions. It is not determined solely by inherent or acquired by an individual characteristics and attitudes. Of course, the potential depends largely on these "personal" factors (i.e. specific characteristics of an individual: permanent and variable) - however, it also depends on the development processes that the individual is subject to (their direction and quality) - and - on external conditions (environment) (compare with: [Łasiński 2016, p. 114]).

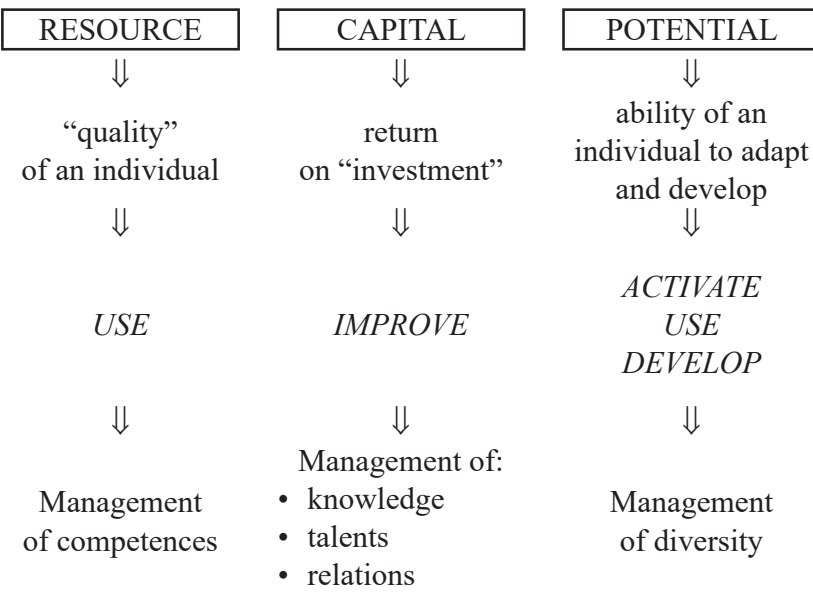

Figure 2. Schematic approach to the conceptual scope of the terms "Resource", "Capital", "Potential"

Source: own study based on [Jamka 2011, pp. 229, 298-299, 304$305,323]$.

In summary - referring to the Social Potential of an organization, the following should be taken into account (compare with [Jabłoński et al. 2015, p. 209]):

- quality and quantity as well as the structure of connections between resources in the possession and disposal of people working for the organization,

- the ability to use the existing system of resources in the possession of people from which the infrastructure of human capital results,

- the context of the processes being implemented: the organization's infrastructure, its structure, climate and culture.

\section{Components of the organization's Social Potential}

Assessing the scale of development opportunities of an employee is extremely difficult, if it is possible to make an unambiguous and reliable estimate at all. It is

\footnotetext{
${ }^{1}$ I.e. the Personal Potential of each employee is part of the Social Potential of the Group and the Personal Potential together with the
} Social Potential of the Group are the components of the Social Potential of the Organization. 
easier to assess the actual (existing at the moment $t_{l}$ ) properties of an individual, rather than predict with a high probability what actual development possibilities they have, and hence, to what extent in the future (i.e. at time $t_{2}$ ) they will demonstrate the ability to adapt.

According to B. Tracy [1993, p. 60-61], the personal potential $\left(\mathrm{PP}_{\mathrm{i}}\right)$, in a simplified way, can be illustrated in the following way:

$$
P P_{i}=\left[C A_{i}+A A_{i}\right]^{*} P A A_{i}
$$

where:

- $\mathrm{CA}_{\mathrm{i}}$ (congenital attributes) - they mean properties of essentially permanent nature, specific and belonging to the individual "inherently" regardless of the activities undertaken by this individual. Here, it is possible to point out, among others: temperament, initial mental, musical and psychomotor predispositions, health.

- $\mathrm{AA}_{\mathrm{i}}$ ("acquired" attributes) - including such "properties" (attributes), which in relation to an individual were developed in a relatively "persistent" manner - which at the same time mean that their development or change occurs over a longer period of time through learning and practicing (repeated actions taken). These include: knowledge, skills, experience, competences.

- $\mathrm{PAA}_{\mathrm{i}}$ (pro-active attitude) - corresponds to a generalized attitude (or mind energy), which embodies a complex construct, including, among others: motivation for achievement, self-awareness, focus on development and self-discipline - and thus to a significant extent referring to factors representing a volatile volition sphere of an individual.

These variables $\left(\mathrm{CA}_{\mathrm{i}}, \mathrm{AA}_{\mathrm{i}}, \mathrm{PAA}_{\mathrm{i}}\right)$ can be described as personal factors of potential, of which the relatively measurable nature ${ }^{2}$ has $\mathrm{CA}_{\mathrm{i}}$ and $\mathrm{AA}_{\mathrm{i}}$.

G. Łasiński [2016, p. 114], referring to the sodefined concept of personal potential $\left(\mathrm{PP}_{\mathrm{i}}\right)$, points out that the level of revealing $\mathrm{PP}_{\mathrm{i}}$ results from the interaction of: consisting of $\mathrm{PP}_{\mathrm{i}}$, the above-described personal factors of potential (being a human resource) and from:

- quality of development processes,

- environment (external conditions).

The indicated quality of development processes refers to all forms of upbringing ${ }^{3}$ and therapy and education $^{4}$ (formal and informal) that the individual had to deal with as well as the types, scope and frequency of activities undertaken by the individual or group. The quality of the indicated development processes is obviously not without significance for the knowledge, skills, competence of the individual experience (acquired attributes).

External conditions refer to the environment in which the individual resides and functions - in its material (available goods, living and learning conditions) and social aspect (family/peer/friend/professional relations, dependence, significant persons).

With reference to the individual employed in the organization in the scope of development processes, the following should be taken into consideration: adaptation processes, team building processes, training, mentoring and coaching, and in terms of external conditions: company structure, communication patterns, technologies used, other employees, employee groups, superior, employment policy, social policy, etc.

In a similar way as in relation to $\mathrm{PP}_{\mathrm{i}}$ (as indicated in the above terminological deliberations), it is possible to determine the potential factors in relation to the group (SPG - Social Potential of the Group), and to the organization as a whole (SOP - Social Potential of the Organization), i.e. it is possible to indicate in the scope of both these potentials (SPG and SPO) factors corresponding to congenital attributes, acquired attributes and pro-active attitude - and analogous categories relevant to the degree to which these potentials can be revealed (see Table 1).

Table 1. Components of human potential at the level of an individual, a group, an organization

\begin{tabular}{|c|c|c|c|}
\hline & Factors of potential & $\begin{array}{l}\text { Development } \\
\text { processes } \\
\text { (DP) }\end{array}$ & $\begin{array}{c}\text { External } \\
\text { conditions } \\
\text { (EC) }\end{array}$ \\
\hline $\begin{array}{l}\text { Level of an } \\
\text { individual }\end{array}$ & $\begin{array}{c}\text { personal factors of } \\
\text { potential: } \\
\mathrm{CA}_{\mathrm{i},} \mathrm{AA}_{\mathrm{i}}, \mathrm{PAA}_{\mathrm{i}} \\
/ \mathrm{PP}_{\mathrm{i}}=\left(\mathrm{CA}_{\mathrm{i}}+\mathrm{AA}_{\mathrm{i})^{*}} \mathrm{PAA}_{\mathrm{i}} /\right.\end{array}$ & $\begin{array}{l}\text { Quality DP } \\
\text { for an } \\
\text { individual }\end{array}$ & $\begin{array}{l}\text { EC of an } \\
\text { individual }\end{array}$ \\
\hline $\begin{array}{l}\text { Level of a } \\
\text { group }\end{array}$ & $\begin{array}{c}\text { group factors of potential: } \\
\mathrm{CA}_{\mathrm{g}}, \mathrm{AA}_{\mathrm{g}}, \mathrm{PAA}_{\mathrm{g}} \\
/ P P_{\mathrm{g}}=\left(C A_{\mathrm{g}}+A A_{\mathrm{g}}\right) * P A A_{\mathrm{g}} /\end{array}$ & $\begin{array}{l}\text { Quality DP } \\
\text { for a group }\end{array}$ & $\begin{array}{l}\text { EC of a } \\
\text { group }\end{array}$ \\
\hline $\begin{array}{l}\text { Level of an } \\
\text { organization }\end{array}$ & $\begin{array}{c}\text { organizational factors of } \\
\text { potential: } \mathrm{CA}_{\mathrm{o}}, \mathrm{AA}_{\mathrm{o}} \text {, } \mathrm{AAA}_{\mathrm{o}} \\
/ P P_{\mathrm{o}}=\left(C A_{\mathrm{o}}+A A_{\mathrm{o}}\right)^{*} P A A_{\mathrm{o}} /\end{array}$ & $\begin{array}{l}\text { Quality DP } \\
\text { within an } \\
\text { organization }\end{array}$ & $\begin{array}{l}\text { EC of an } \\
\text { organiza- } \\
\text { tion }\end{array}$ \\
\hline
\end{tabular}

Source: own study.

In the case of a group, in terms of "congenital attributes" $\left(\mathrm{CA}_{\mathrm{g}}\right)$ the significance will be the number and "quality" of the group's composition (therefore both what $\mathrm{PP}_{\mathrm{i}}$ each group member has and what the configuration $\mathrm{PP}_{\mathrm{i}}$ in the group is) - how the group has been embedded in the organization structure (what rights and resources have been allocated to this

\footnotetext{
${ }^{2}$ So it can be documented.

${ }^{3}$ Including patterns of internalized culture.

${ }^{4}$ Including also coaching.
} 
group). With regard to "acquired attributes" $\left(\mathrm{AA}_{\mathrm{g}}\right)$, for example, at what stage of development a particular group is, the importance will have its structure, the level of cohesion, the distribution of roles and experience and internal culture ${ }^{5}$. In turn with respect to the proactive attitude of the group ( $\mathrm{PAA}_{\mathrm{g}}$ ), it seems important that the high individual-level causative attitude of the group members $\left(\mathrm{PAA}_{\mathrm{g}}\right.$ ) does not guarantee the causative attitude of the group (PAA $)_{\mathrm{g}}$. In many cases, $\mathrm{PAA}_{i}$ is of course significant for shaping the category, which is PAA, but it is not a guarantee of a high PAA . Both the situation in which the PAA $_{i}$ for an n-person group will be smaller than the average $\mathrm{PAA}_{\mathrm{g}}$ in the group and the situation in which it will be equal or greater is possible. In relation to the group, it is also possible to indicate and evaluate the quality of DP and the nature of external conditions. Similarly, (at a higher level of generalization) it is possible to do it in relation to the organization. Because the subject matter is very broad, in the further part of the article the attention will be focused on the individual level.

\section{Conditions for shaping potential in the organization}

It should be noted that each of the described elements determining the level of revealing the potential may be shaped in the organization in a more or less favourable way. For further considerations, it was assumed (to some extent) that each factor may adopt the optimal or suboptimal state (Table 2).

Table 2. Types and nature of factors conditioning the level of potential disclosure

\begin{tabular}{|l|l|l|l|l|}
\hline & & \multicolumn{3}{|c|}{ Type of factor } \\
\hline & $\begin{array}{l}\text { factors of } \\
\text { potential }\end{array}$ & $\begin{array}{l}\text { quality of } \\
\text { development } \\
\text { process }\end{array}$ & $\begin{array}{l}\text { external } \\
\text { conditions }\end{array}$ \\
\hline $\begin{array}{l}\text { Nature } \\
\text { of factor }\end{array}$ & optimal & $\begin{array}{l}\text { highly adequate } \\
\text { to the assigned } \\
\text { tasks (PF+) }\end{array}$ & $\begin{array}{l}\text { high } \\
(\mathrm{DP}+)\end{array}$ & $\begin{array}{l}\text { favourable } \\
(\mathrm{EC}+)\end{array}$ \\
\hline & $\begin{array}{l}\text { sub- } \\
\text { optimal }\end{array}$ & $\begin{array}{l}\text { less adequate to } \\
\text { the assigned tasks } \\
\text { (PF-) }\end{array}$ & $\begin{array}{l}\text { low } \\
(\mathrm{DP}-)\end{array}$ & $\begin{array}{l}\text { less } \\
\text { favourable } \\
\text { (EC-) }\end{array}$ \\
\hline
\end{tabular}

Source: own study.
Thus, personal factors may be more or less adequate to the assigned tasks ${ }^{7}$, the quality of the development process - high or low ${ }^{7}$ and external conditions favouring or not conducive to the development of potential ${ }^{8}$. Taking into account possible states of combinations of the discussed factors, we propose to distinguish the following eight situations in the organization when:

- all factors reach optimal condition: $(\mathrm{PF}+\mathrm{DP}+\mathrm{EC}+)$ $\rightarrow$ Sorbonne,

- none of the indicated factors qualify for recognition as optimal: (PF-DP-EC-) $\rightarrow$ Sahara,

- only the system of personal factors is very beneficial: (PF+DP+EC-): $\rightarrow$ The art of survival,

- only the external conditions system is very beneficial: (PF-DP-EC+) $\rightarrow$ Endemit,

- only development processes are shaped favourably: (PF-DP+EC-) $\rightarrow$ Reggae on ice,

- favourable arrangement applies only to personal factors and development processes ( $\mathrm{PF}+\mathrm{DP}+\mathrm{EC}-)$ $\rightarrow$ Commandos,

- when personal factors and external conditions are optimal: $(\mathrm{PF}+\mathrm{DP}-\mathrm{EC}+) \rightarrow$ Rentier,

- favourable arrangement applies only to development processes and external conditions $(\mathrm{PF}-\mathrm{DP}+\mathrm{EC}+) \rightarrow$ Nursery.

These situations were graphically presented in Figure 3.

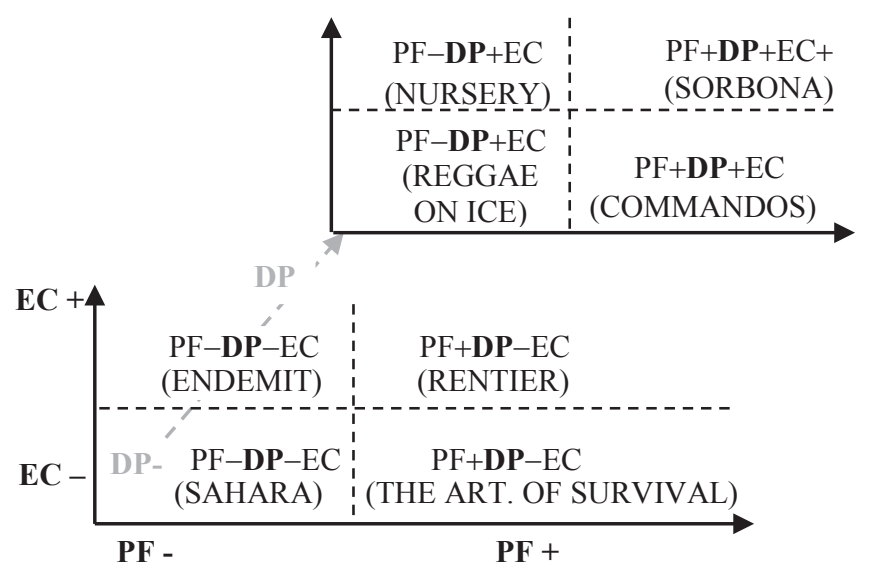

Figure 3. A box of types of situations from the point of view of assessing potential activating capabilities

Source: own study.

\footnotetext{
${ }^{5}$ It seems also essential to consider the network of connections developed by the individuals included in the group as this group's representatives.

${ }^{6}$ I.e. in the area of CA or AA, more or less adequate and sufficient to perform tasks assigned to the employee - and due to the level of PAA used/developed in the relevant scope.

${ }^{7}$ In terms of the form, type, scope and frequency of activities carried out within these processes and their adequacy for the entity (group of entities) concerned.

${ }^{8}$ In the material and social aspect of the work environment (group, department, organization). From the subjective point of view of individual employees, these conditions can sometimes be considered as discouraging (unfavourable) and thus have a limiting effect on PAA .
} 
It seems that just identifying the type of situation in the above manner would facilitate making decisions, actions in the field of organization policy, appropriate for shaping, using and developing the potential.

For instance, in the case when personal factors are highly adequate to the assigned tasks $(\mathrm{PF}+)$, it will be possible through activities conducive to achieving a high quality development process and/or providing the right environment. When personal factors and the quality of the development process are high $(\mathrm{PF}+$, $\mathrm{DP}+$ ), it is enough "not disturb", caring for supporting external conditions. However, when personal factors and the environment are appropriate $(\mathrm{PF}+\mathrm{IC}+)$, it is necessary to take measures to broaden/deepen the abilities and skills of employees.

However, in practice, making decisions about appropriate actions that shape the potential turns out to be much more complex in situations where personal factors are not adequate to the assigned tasks (PF-). This is a natural consequence of the essence of $\mathrm{PP}_{\mathrm{i}}$ reflected in the accepted notation of the formula for personal potential $/ \mathrm{PP}_{\mathrm{i}}=\left[\mathrm{CA}_{\mathrm{i}}+\mathrm{AA}_{\mathrm{i}}\right] * \mathrm{PAA}_{\mathrm{i}} /$. When the situation (PF-) is conditioned only by congenital attributes (CA), it should lead organizations to analyse the availability of human resources, the applied procedure of the recruitment process and the effectiveness of selection. When it depends mainly on acquired attributes (AA), it would be reasonable to concentrate on development processes. When the "problem" is in PAA, it is difficult to clearly indicate the type of desired activities. The pro-active attitude (as already pointed out), is a complex construct representing the volatile sphere of the individual, quite variable over time. When $\mathrm{PAA}_{\mathrm{i}}$ is equal to zero or close to zero, then (regardless of the size of $\mathrm{CA}_{\mathrm{i}}$ or $\mathrm{AA}_{\mathrm{i}}$ ), the potential will not only be unrevealed (and as a result will not be used), but its development will be prevented. In other words, without PAA, it is difficult to talk about the favourable value of $\mathrm{PP}_{\mathrm{i}}$. In this case, focusing on DP will not bring the expected results. PAA determines the difference between those who "know what to do to achieve success" and those who "do it and achieve that success" [Łasiński 2016, p. 115]. From the point of view of shaping potential (regardless of the level of its consideration), PAA is a key factor, but also the most difficult to obtain. From the point of view of the organization, the possibility of PAA modelling seems (due to its "embedding" in the individual) basically limited to the issue of shaping engagement. Regardless of the way in which engagement is defined, willingness is considered to be its essence. Moreover, W.B. Schaufeli and A.B. Bakker [2004, p. 295] define work engagement as "a positive state of mind, connected with work, characterized by vigour, preoccupation and devotion". Vigour means a high level of energy, psychological resistance at work and willingness to invest effort, perseverance in the face of emerging difficulties. Preoccupation is being busy, experiencing sense of meaning, enthusiasm, inspiration, pride and challenge. Devotion involves focusing on work and being absorbed by work, characterized by a lack of perceiving the passage of time and difficulties in getting away from work. For this reason, it is difficult to disagree with the statement that the potential of a particular entity can be fully used only when obtaining the involvement of the entity concerned. This is indirectly confirmed by the constant development of WLBP (Work-Life Balance Program) and HPWS (High Performance Work Systems) or HIWP (High Involvement Work Practices). Systems according to Z. Antczak [2014, pp. 18-19], are a natural response from economic practice, both to the increase in the subjectivity of the position of highly qualified employees and the associated "side effects of the self-empowerment and professionalization of hyper-professionals"

In the context of the deliberations and preformulated conclusions, one more conclusion is emerging. From the point of view of PAA, it will be (and is) important how the EC are subjectively assessed by the individual (employee). In the problem of shaping the Social Potential, the need to consider the additional category of job satisfaction (related to the EC assessment from this subjective perspective) is also marked. Satisfaction from work is defined as an emotional reaction of pleasure or distress experienced in connection with the performance of specific tasks, functions and roles [Bańka 2000, p. 329]. Furthermore, the literature on the subject emphasizes the existence of a link between the level of job satisfaction and the strength of attachment to the organization ${ }^{9}$ and the intensity of manifestations of civic organizational behaviour $^{10}$ [Jung, Yoon 2015, pp. 1136, 1145; Edmans 2012, pp. 1-2; Bańka 2000, p. 331; Egan et. al. 2004, p. 283] (Fig. 4). Lack of job satisfaction is associated with hindering the acceptance of the organization's values and goals, reducing the will to spend the effort on behalf of the employees (lowering involvement in the work performed) and fostering lowering the loyalty of the employees towards the parent organization [Fulmer et al. 2003, pp. 967, 987988].

\footnotetext{
${ }^{9}$ I.e. the desire to continue employment within its framework (preferring to stay in the organization).

${ }^{10}$ I.e. development of pro-social attitudes that are important from the point of view of collision-free functioning of the organization.
} 
How the satisfaction and commitment categories are shaped, on the one hand, gives information on how PAA can be assessed and what is the assessment of the EC on the part of the individual. On the other hand, the total consideration of these categories (see Figure 4) allows for a more accurate assessment of the general situation from the point of view of the possibility for shaping the potential and activities which in this respect prove to be the most adequate.

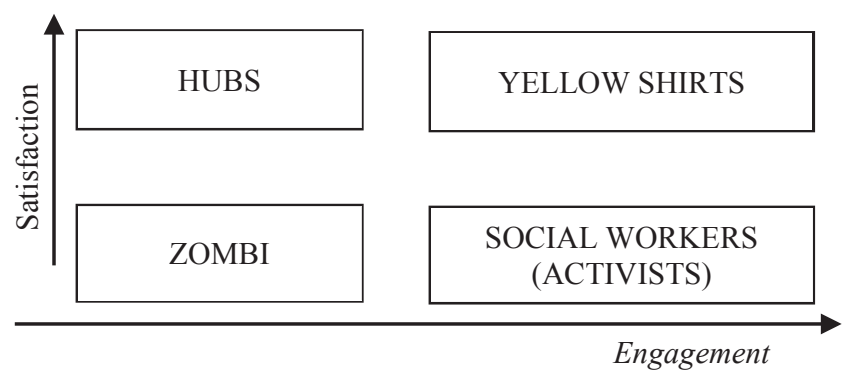

Figure 4. The link between the level of job satisfaction and engagement

Source: own study.

It can be assumed that in case of:

1. Yellow Shirts (high level of satisfaction, high level of engagement), i.e. people who are almost always strongly involved in the work and are almost ideal employees, it will be important to take supporting actions to maintain their involvement. It may also be important to ensure that these people are not affected by burn-out.

2. Hub (high level of satisfaction, low level of engagement), i.e. persons who positively assess their situation (declare satisfaction) and at the same time "give up" in many matters, engage at a low level. It seems that in order to make the most of their potential it would be advisable to concentrate on building PAA.

3. Social Workers (low level of satisfaction, high level of engagement), i.e. people who are highly loyal and who, despite lack of satisfaction, engage in work in the long term. They may find it important to pay attention to EC and probably, at the same time, concentrate on the change of EC perception.

4. Zombies (low level of satisfaction, low level of engagement), i.e. persons who rarely engage (often do only what survival requires), and at the same time often express their dissatisfaction and demotivate others. It is worth considering parting. The decision can be based on an assessment of the effectiveness of the engagement-enhancing measures applied and the amount of financial outlays incurred.

\section{Instead of the conclusion}

The presented approach is only a preliminary outline of the concept, which still requires an in-depth analysis and development. Nevertheless, the findings may seem interesting from the point of view of their potential practical value in defining the desired directions and scope of the organization's activities in the context of using and developing the Social Potential (especially taking into account outlined relations of satisfaction and engagement). In the longer term, it seems reasonable to seek answers to, among others, such questions as:

1. What are the dependencies between factors determining the level of potential disclosure?

2. Is it possible to talk about the hierarchy of factors shaping the potential?

3. What specific actions should be taken with a particular set of factors for shaping the potential?

Each of these questions should be referenced to all the three levels of Potential's consideration in the organization (individual, group, organizational) separately.

\section{References}

Antczak Z., 2014, Ku kapitałowi ludzkiemu: trendy ewolucji funkcji personalnej w okresie ćwierćwiecza transformacji gospodarczo-spolecznej w Polsce, Prace Naukowe Uniwersytetu Ekonomicznego we Wrocławiu, nr 349.

Bańka A., 2000, Psychologia organizacji, [in:] J. Strelau (ed.), Psychologia - podręcznik akademicki, tom III: Jednostka w społeczeństwie i elementy psychologii stosowanej, Gdańskie Wydawnictwo Psychologiczne, Gdańsk.

Becton J.B., Schraeder M., 2009, Strategic human resources management: Are we there yet?, Journal for Quality and Participation, vol. 31 , no. 4, pp. 11-18.

Costello M., 2011, Team Weaver - Michael Costello interviews Meredith Belbin, People Management, 27th January.

Edmans A., 2012, The link between job satisfaction and firm value, with implications for Corporate Social Responsibility, Academy of Management Perspectives, vol. 26, iss. 4, pp. 1-19.

Egan T.M., Yang B., Bartlett K.R., 2004, The effects of organizational learning culture and job satisfaction on motivation to transfer learning and turnover intention, Human Resource Development Quarterly, no. 15 (3).

Fulmer I.S., Gerhart B., Scott, K.S., 2003, Are the 100 best better? An empirical investigation of the relationship between being a "great place to work" and firm performance, vol. 56, iss. 4, pp. 965-993.

Grabowska A., Gródek-Szostak Z., Jando O., Kajrunajtys D., 2018, Uwarunkowania podejmowania wspólpracy przez przedsiębiorców, [in:] M. Makowiec, B. Mikuła, A. Pietruszka-Ortyl (eds.), Wybrane problemy zarzadzania $w$ gospodarce opartej na wiedzy - teoria i praktyka, Katedra Zachowań Organizacyjnych - Uniwersytet Ekonomiczny w Krakowie, Kraków, pp. 137-149.

Hysa B., Grabowska B., 2017, Wiedza, umiejętności oraz potencjat pracowników administracji publicznej na przykładzie 
wybranej jednostki ZUS, Zeszyty Naukowe Politechniki Śląskiej, z. 113, nr kol. 1992.

Jabłoński M., Łukasik P., Makowiec M., Mikuła B., Pietruszka-Ortyl A., Winkler R., 2015, Inicjatywy doskonalace potencjat spoteczny przedsiębiorstwa, [in:] Wybrane problemy $w$ ksztattowaniu zachowań organizacyjnych, Wyd. UE w Krakowie, Kraków.

Jamka B., 2011, Czynnik ludzki we współczesnym przedsiębiorstwie: zasób czy kapitat?, Wolters Kluwer, Warszawa.

Janowska A.A., Skrzek-Lubasińska M., 2019, Kompetencje przyszłości w warunkach ekspansji gospodarki 4.0, Studia Ekonomiczne, no. 379, pp. 57-71.

Jung H.S., Yoon H.H., 2015, The impact of employees' positive psychological capital on job satisfaction and organizational citizenship behaviors in the hotel, International Journal of Contemporary Hospitality Management, vol. 27, iss. 6, pp. 1135-1156.

Łasiński G., 2016, Potencjat pracowników. Istota, obszary i skale, Prace Naukowe Uniwersytetu Ekonomicznego we Wrocławiu, $\mathrm{nr} 429$.

Mikuła B., 2014, Rozwój potencjału spolecznego przedsiębiorstwa $w$ warunkach gospodarki opartej na wiedzy, [in:]
A. Stabryła, S. Wawak (eds.), Problemy zarządzania organizacjami w spoleczeństwie informacyjnym, MFiles.pl, Kraków.

Pawlak Z., Smoleń A., 2007, Etyczne problemy zarzadzania potencjatem społecznym $w$ przedsiębiorstwie, Annales: etyka w życiu gospodarczym 2007, tom 10, nr 1 .

Schaufeli W.B., Bakker A.B., 2004, Job demands, job resources, and their relationship with burnout and engagement: A multi sample study, Journal of Organizational Behavior, no. 25.

Smoleński S., 2001, Zarzadzanie potencjałem pracowniczym $w$ przedsiębiorstwie, Oficyna Wydaw. Ośrodka Postępu Organizacyjnego, Bydgoszcz .

Smykowski B., 2019, Aktualizacja potencjału człowieka jako kryterium pomyślności jego rozwoju, Nauka, nr 1, pp. 121-136.

Tracy B., 1993, Maximum Achievement: Strategies and Skills that Will Unlock Your Hidden, Simon \& Schuster Paperbacks, New York-London-Toronto-Sydney.

Коваль О.О., 2012, Модель використання сочіального потенщіалу машинобудівного підприємства, Вісник Дніпропетровського університету. Серія «Економіка», №. 6 (2).

Полякова Е. І., 2008, Управління посилення економічної безпеки підприсмства для функиій цүіональною складовою соиіальний потенцііал, „Наукові праці ДонНТУ. Серія економічна", No.33.

\section{PROLEGOMENA: POTENCJAL SPOLECZNY ORGANIZACJI A ZAANGAŻOWANIE I SATYSFAKCJA Z PRACY}

Streszczenie: W artykule uwagę skoncentrowano na potencjale społecznym organizacji. Zgodnie z przyjętym celem opisano składowe potencjału i scharakteryzowano warunki jego kształtowania w organizacji. Uwzględniając możliwe stany zestawień omówionych czynników potencjału, zaproponowano typy sytuacji ważne dla oceny możliwości aktywowania potencjału. Dokonano ich analizy, z jednej strony wskazując na działania z zakresu polityki organizacji, odpowiednie dla kształtowania, wykorzystania i rozwijania potencjału, z drugiej - ukazując złożoność zagadnienia i trudności w doborze rodzaju działań. Ukazano znaczenie zaangażowania i satysfakcji w tym zakresie.

Słowa kluczowe: potencjał społeczny, organizacja, satysfakcja z pracy, zaangażowanie. 